\title{
Influence of Fuel System, Fuels Types and Spark Plug Types on CO Gas Exhaust of Motorized Vehicles
}

\author{
Udin Komarudin
}

Department of Mechanical Engineering, Widyatama University, Indonesia

Copyright $\mathrm{C} 2019$ by authors, all rights reserved. Authors agree that this article remains permanently open access under the terms of the Creative Commons Attribution License 4.0 International License

\begin{abstract}
Fuel system, type of fuel and type of spark plug, are the determining variables in producing exhaust gas in motorized vehicles. Pollutants produced by motor vehicle emissions include Carbon Monoxide (CO), carbon dioxide $\left(\mathrm{CO}_{2}\right)$, Sulfur Dioxide $\left(\mathrm{SO}_{2}\right)$, Nitrogen Monoxide (NOX), Hydrocarbons (HC), Lead Particles (PB), smoke and ash. These pollutants can cause interference in humans, animals, plants and other objects. The study was conducted to determine the effect of the main variables of the fuel system variables (Carburetor and EFI), type of fuel (Premium octane 88 and Pertamax octane 92) and the type of spark plugs (standard spark plugs and spark plugs Iridium) on $\mathrm{CO}$ gas exhaust. The test tool used to determine the value of the percentage of vehicle exhaust is a Gas Analyzer and the test vehicle used is a 4-step motorcycle. The research method uses factorial design and variable analysis using Yates's algorithm. The test results show that the effect of the fuel system is $-1,272$ (Carburetor), the effect of fuel type is -0,268 (Premium), and the type of spark plug is -0,018 (standard spark plug), so the most influential variable on CO gas output is the fuel system using the Carburetor.
\end{abstract}

Keywords Carburetor, Gas Analyzer, CO, Factorial Design

\section{Introduction}

The fuel system, the type of fuel and the type of spark plugs, are important of a motorized vehicle. Changes to the fuel system from the Carburetor to Electronic Fuel Injection (EFI) are technological changes in setting the amount of fuel and air entering the combustion chamber. Comparison of the volume of fuel and the air entering the combustion chamber, greatly determines the output of combustion (exhaust gas).

The development of premium fuels (octane 88) and pertamax (octane 92), as well as the types of spark plugs
Standard and Iridium, are technological developments, one of which is to improve vehicle efficiency and be environmentally friendly.

Tests are carried out to determine the greatest effect on exhaust gas Carbon monoxide (CO), from the vehicle fuel system, the type of fuel used and the type of spark plug used.

Gas CO is a gas that is very dangerous for health. If a person breathes $\mathrm{CO}$ gas in low levels, that person can experience shortness of breath and pale. But if in a high levels can cause fainting, even death. Gas that is colorless, odorless, tasteless and non-stimulating, therefore carbon monoxide gas is difficult to detect.

Community knowledge of variables that produce $\mathrm{CO}$ gas is very necessary. This is to anticipate the possibility of an accident due to exhaust gas CO. With this knowledge, it is expected that people can choose the type of vehicle and the type of fuel that will be used

\section{Fuel System}

On the Otto engine there is a fuel system consisting of a fuel supply system and a fuel gauge system. The fuel supply system functions to deliver fuel from the fuel tank to the fuel gauge system. Whereas the Fuel Gauge system on the Otto engine that uses a carburetor or fuel injection system functions as follows:

- Measure the amount of air and fuel to obtain a mixture of air fuel that can be burned quickly and perfectly in the cylinder.

- Atomizing and spreading fuel in the air flow or known as Air Fuel Ratio (AFR).

The parameter is called Air Fuel Ratio (AFR), which is the ratio of the amount of air to fuel in weight. The theoretical comparison value for the perfect combustion process or also called stoichiometric AFR for the Otto motor is around 14.7. The fuel system must be able to produce an air ratio of the fuel needed to be cylinder in accordance with the engine operating conditions. For 
example at cold start times, a mixture that is rich in fuel is needed. In the condition that the engine is still cold automatically, the fuel that evaporates is only partially so that additional fuel is needed to obtain the mixture which is ready to be burned in the cylinder. The construction of the carburetor is simple and has been used in almost all of the engine Otto in the past. But lately, in order to fulfill the demand to clean exhaust gas (exhaust emission), the use of fuel that is more economic, improved driving capability and so on, the current carburetor must be equipped with additional equipment to make the carburetor system complicated.

To replace the carburetor system, then the EFI (Electronic Fuel Injection) fuel system is used, which is injecting fuel done electronically equipped with sensors to detect engine working conditions and ECU (electronic control unit) to determine the duration of fuel injection and set ignition time.

The differences between the carburetor and efi systems are as follows

a) How it works to mix fuel with air.

In the carburetor system, mixing fuel and air is caused by the vacuum of the combustion chamber which occurs due to the step of suction piston. If on the EFI injection system, mixing fuel and air is done by the injector on the orders of the ECU which considers signals from sensors that spread throughout the engine and exhaust.

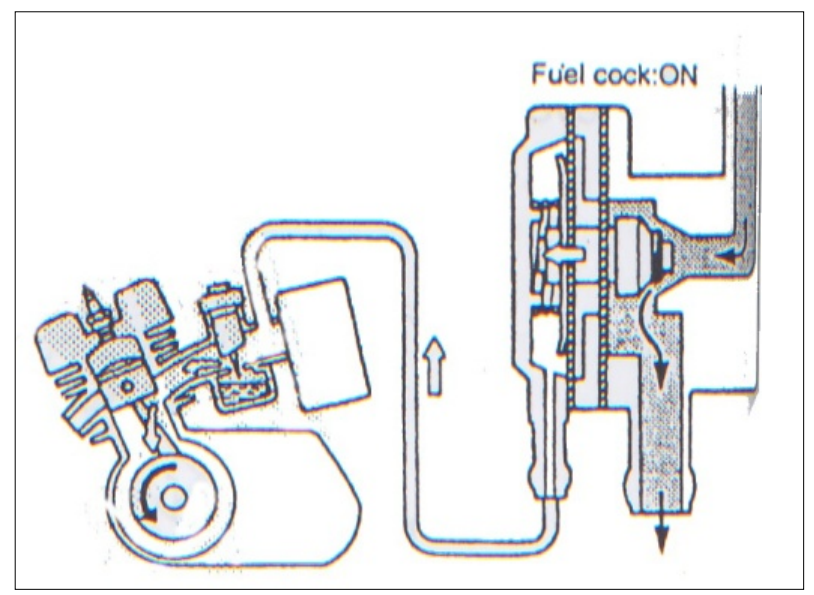

Figure 1. Carburetor system

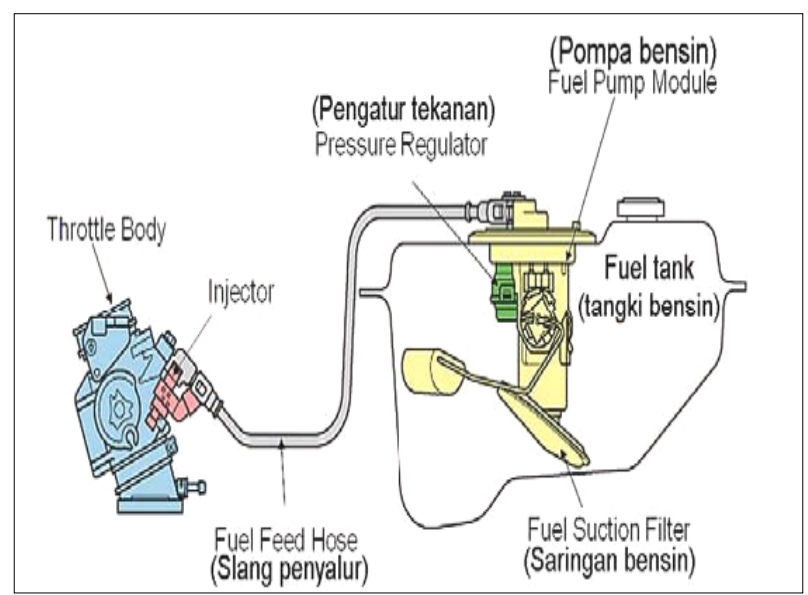

Figure 2. EFI injection system

b) When the engine temperature is cold.

When the engine temperature is cold the engine requires a rich mixture of gasoline to start the engine. In the carburetor system, to enrich the gasoline mixture, choke is activated so that the fuel ratio becomes rich. For the fuel injection system, the temperature sensor will report the cold engine temperature so that the ECU instructs the injector to enrich the gasoline mixture.

c) At the time of acceleration.

At the time of motor acceleration requires a mixture of fuel that is quite rich around 8: 1 AFR. The carburetor system is assisted by an accelerator nozzle which functions to increase the supply of fuel to the engine when the gas throttle is opened suddenly. If the throttle position sensor injection system will send a report to the ECM that the throttle is opened suddenly and the ECM will instruct the injector to enrich the gasoline mixture.

d) At high rpm.

At high rpm, the main jet carburetor and jet pilot systems are fully open to produce a large amount of power. If the fuel injection system, the throttle position sensor and vacuum sensor in the intake manifold both send a signal to the ECM to slightly enrich the mixture. 


\section{Emissions}

Exhaust gas emissions are pollutants that pollute the air produced by vehicle exhaust gas (Wardan Suyanto, 1989: 345). The vehicle exhaust gas intended here is the remaining gas from the combustion process which is discharged into the air through the vehicle's exhaust line. The four emissions are Hydrocarbon (HC) compounds, Carbon Monoxide (CO), Nitrogen Oxide (NOx), and particles that emit from the exhaust gas.

a) Hydrocarbon Compounds (HC).

It occurs because the fuel has not been burned but has been wasted with the exhaust gas due to incomplete combustion and evaporation of fuel. Hydrocarbon compounds (HC) are divided into two namely unburned fuels so that it comes out into raw gas, and the fuel is broken down because the heat reaction turns into another HC group that comes out with the exhaust gas.

$$
\mathrm{C}_{8} \mathrm{H}_{18} \rightarrow \mathrm{H}+\mathrm{C}+\mathrm{HC}
$$

b) Fire produced by spark plugs in the combustion chamber moves very fast but the temperature around the walls of the combustion chamber is low. This results in a mixture of fuel and air in the low temperature area that is quenching zone. The unburned fuel mixture is then pushed out by the piston to the exhaust

c) At the time of deceleration, the gas valve (throttle valve / valve) closes so that the engine brake occurs even though the engine speed is still high. This will cause a large amount of fuel suction, the mixture becomes very rich and many unburned fuels are wasted. (on the carburetor fuel system)

d) Overlapping steps (the inlet and exhaust valves together open) are too long so the $\mathrm{HC}$ functions as a rinse / cleaning gas (occurs especially at low speed, carburetor fuel systems). HC compounds will have an impact on the eyes, resulting in throat pain, lung disease and cancer. Graph of the relationship between air-fuel mixture and $\mathrm{HC}$ can be observed in the figure below.

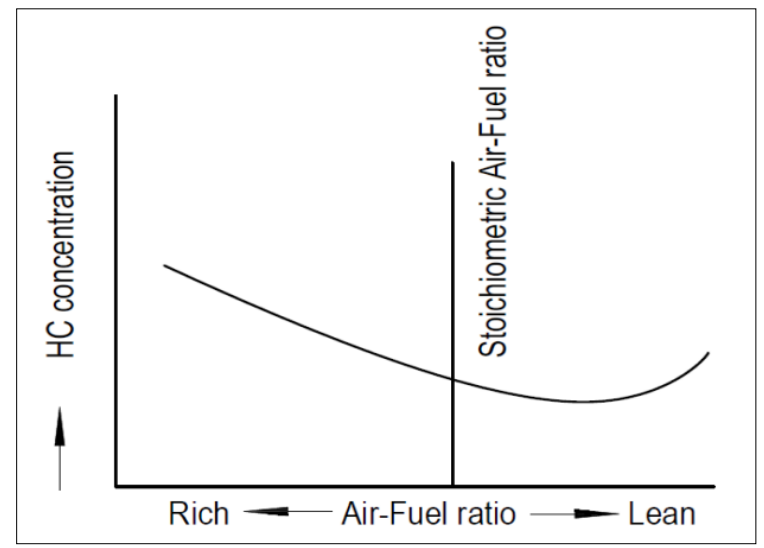

Figure 3. Relationship between Mixtures Air-Fuel and HC e) Carbon monoxide (CO), created from fuel that is partially burned due to incomplete combustion or due to a mixture of fuel and air that is too rich (lack of air). The carbon element in the fuel will burn in a process as follows:

$$
2 \mathrm{C}+\mathrm{O}_{2} \rightarrow 2 \mathrm{CO}
$$

$\mathrm{CO}$, which is released from the remaining combustion products, is largely influenced by the ratio of the mixture of fuel and air sucked by the engine. To reduce $\mathrm{CO}$ the comparison of this mixture must be made thin, but this method has other side effects, namely NOx will be easier to arise and the energy produced by the engine will decrease. $\mathrm{CO}$ is very dangerous because it is colorless and odorless, resulting in dizziness, nausea, breathing disorders, and even death. The graph of the relationship between a mixture of air-fuel, $\mathrm{CO}$ and $\mathrm{CO}_{2}$ can be observed in the figure below.

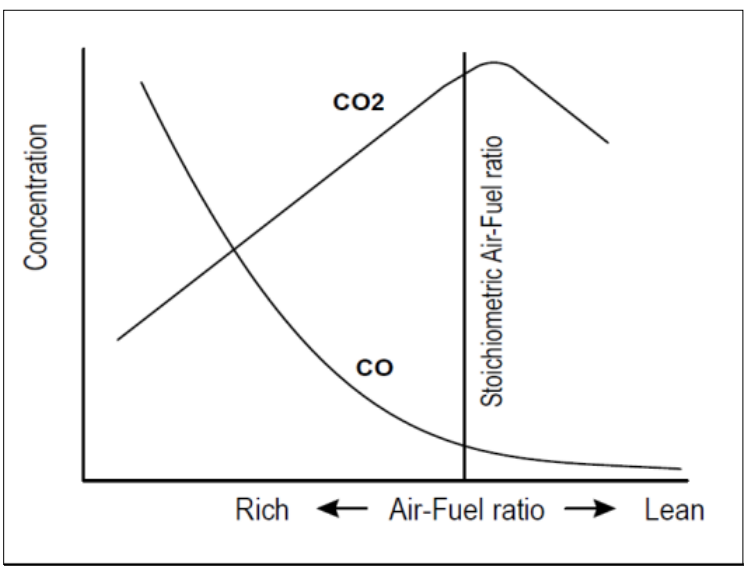

Figure 4. Relationship between Mixtures Air-Fuel, $\mathrm{CO}$ and $\mathrm{CO}_{2}$

\section{Methodology}

The method used in the study was using factorial design and Yates' algorithm.

\section{a. Factorial Design}

Factorial design is a method that is very important to determine the influence of several variables that affect results. Conventional experiments only measure one influence of one variable to find out the results. The factorial design can combine several variables in the same factorial test, besides that it can reduce the number of unnecessary experiments. With factorial design values can be known.

\section{Basic principles}

(Example) If there are 3 variables Temperature $\mathrm{T}$, Concentration $\mathrm{C}$ and Catalist $\mathrm{K}$, will be analyzed, where each variable has 2 specific values (- and + ), to determine the effect of each variable, then factorial design $2^{3}$.

Then the factorial design is: 


\begin{tabular}{|c|c|c|c|c|c|}
\hline \multicolumn{2}{|c|}{ Temperatur, $\boldsymbol{T}\left({ }^{\circ} \mathrm{C}\right)$} & \multicolumn{2}{|c|}{$\begin{array}{r}\text { Concentration, } \\
(\%)\end{array}$} & \multicolumn{2}{c|}{ Catalyst, $\boldsymbol{K}$} \\
\hline- & + & - & + & - & + \\
160 & 180 & 20 & 40 & $\mathrm{~A}$ & $\mathrm{~B}$ \\
\hline
\end{tabular}

So with factorial design, 8 trials were obtained $\left(2^{3}=8\right)$.

\begin{tabular}{|c|c|c|c|c|}
\hline No & $\mathbf{T}$ & $\mathbf{C}$ & $\mathbf{K}$ & $\begin{array}{c}\text { Hasil Pengujian } \\
(\text { contoh, } y \%)\end{array}$ \\
\hline 1 & - & - & - & 60 \\
\hline 2 & + & - & - & 72 \\
\hline 3 & - & + & - & 54 \\
\hline 4 & + & + & - & 68 \\
\hline 5 & - & - & + & 52 \\
\hline 6 & + & - & + & 83 \\
\hline 7 & - & + & + & 45 \\
\hline 8 & + & + & + & 80 \\
\hline
\end{tabular}

\begin{tabular}{|c|c|c|c|c|}
\hline $\begin{array}{c}\text { Run } \\
\text { Number }\end{array}$ & $\begin{array}{c}\text { Temperatur } \\
\boldsymbol{T}\left({ }^{\circ} \boldsymbol{C}\right)\end{array}$ & $\begin{array}{c}\text { Concentration } \\
\boldsymbol{C}(\%)\end{array}$ & $\begin{array}{c}\text { Catalyst } \\
\boldsymbol{K}(\boldsymbol{A} \text { or } \boldsymbol{B})\end{array}$ & $\begin{array}{c}\text { Hasil } \\
\boldsymbol{y}(\%)\end{array}$ \\
\hline 1 & 160 & 20 & $\mathrm{~A}$ & 60 \\
\hline 2 & 180 & 20 & $\mathrm{~A}$ & 72 \\
\hline 3 & 160 & 40 & $\mathrm{~A}$ & 54 \\
\hline 4 & 180 & 40 & $\mathrm{~A}$ & 68 \\
\hline 5 & 160 & 20 & $\mathrm{~B}$ & 52 \\
\hline 6 & 180 & 20 & $\mathrm{~B}$ & 83 \\
\hline 7 & 160 & 40 & $\mathrm{~B}$ & 45 \\
\hline 8 & 180 & 40 & $\mathrm{~B}$ & 80 \\
\hline
\end{tabular}

\section{b. Yates's algorithm}

Yates's algorithm is a method for determining the main effects of each variable and the effect of a variable relationship. After the results of the factorial design test were obtained, then processed these values with Algorithm Yates's, as follows:

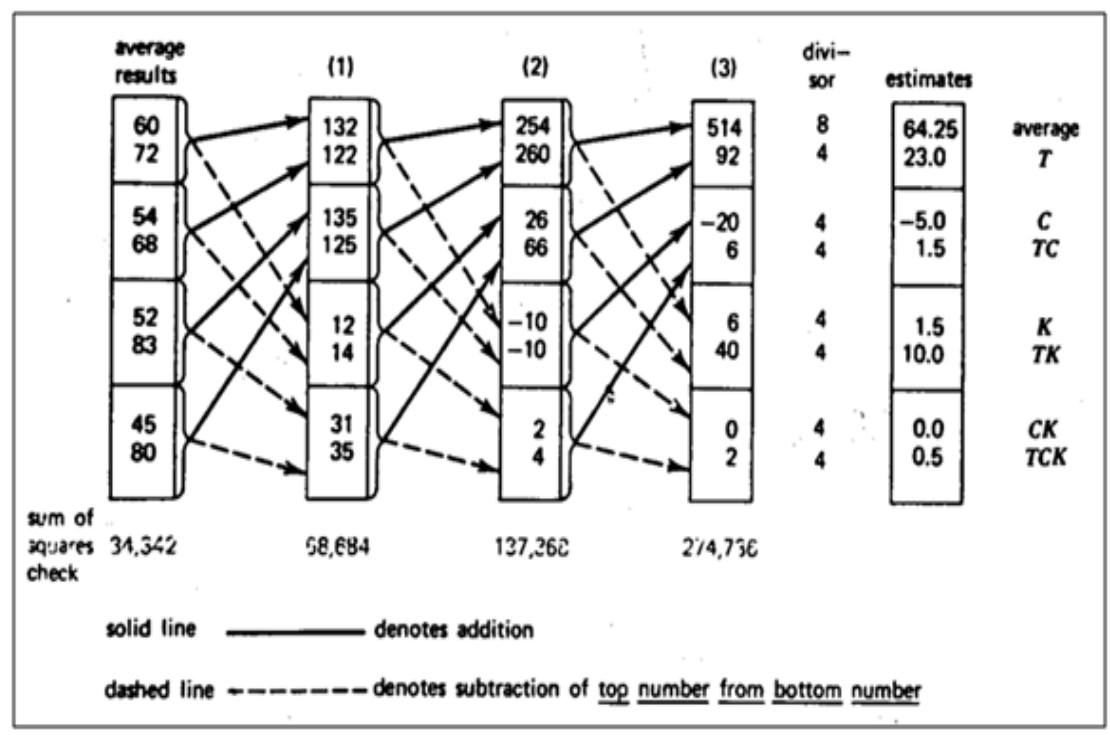

Figure 5. Yates's Algorithm Tabulation 
From processing data, the influence of variables is as follows:

Influence:

Temperature, $\mathrm{T}(\mathrm{oC})=23$.

Concentration, $\mathrm{C}(\%)=-5.0$

Catalyst, $\mathrm{K}(\mathrm{A}$ or $\mathrm{B})=1.5$

Temperature $(\mathrm{T})+$ Concentration $(\mathrm{C})=1.5$

Temperature $(\mathrm{T})+$ Catalyst $(\mathrm{K})=10.0$

Concentration $(\mathrm{C})+$ Catalyst $(\mathrm{K})=0.0$

$\mathrm{T}+\mathrm{C}+\mathrm{K}=0.5$

From processing, the most influential sequence of variables is:

Individual effect

Variable Temperature $=23.0$

Instruction effect

Variable Temperature + Catalyst $=10.0$

\section{Experiment}

\section{a. Experiment Design}

The design of the experiment is based on the factorial design method, where there are 3 variables (fuel system FS, fuel type FT and spark plug type SPT) which are then determined by 2 testing limits ('-' and '+ '). Next, with the factorial design method, the number of experiments is:

Number of Experiments $=2^{\mathrm{n}}$,

Where, $\mathrm{n}=$ variable tested $=3$

Then, trial $=2^{3}=8$ Experiments

Initial design of the experiment

\begin{tabular}{|c|c|c|c|c|c|}
\hline \multicolumn{2}{|c|}{ FS } & \multicolumn{2}{|c|}{ FT } & \multicolumn{2}{c|}{ SPT } \\
\hline- & + & - & + & - & + \\
\hline
\end{tabular}

\begin{tabular}{|c|c|c|c|c|}
\hline No & FS & FT & SPT & Result \\
\hline 1 & - & - & - & \\
\hline 2 & + & - & - & \\
\hline 3 & - & + & - & \\
\hline 4 & + & + & - & \\
\hline 5 & - & - & + & \\
\hline 6 & + & - & + & \\
\hline 7 & - & + & + & \\
\hline 8 & + & + & + & \\
\hline
\end{tabular}

Where for the testing limit values ('-" and '+ ') are as follows:

1. Fuel System (FS)

"+" = Electronic Fuel Injection (EFI)

"-" = Carburetor (Carbu)

2. Fuel Type (FT)

"+" = Pertamax, octane $92(92)$

"-"= Premium, octane 88 (88)
3. Spark Plug Type (SPT)

$$
\begin{array}{ll}
\text { "+" } & =\text { Iridium (IRD) } \\
\text { "-" } & =\text { Standard (STD) }
\end{array}
$$

So that the initial experimental design becomes:

\begin{tabular}{|c|c|c|c|c|c|}
\hline \multicolumn{2}{|c|}{ FS } & \multicolumn{2}{c|}{ FT } & \multicolumn{2}{c|}{ SPT } \\
\hline Carbu & EFI & 88 & 92 & STD & IRD \\
\hline
\end{tabular}

\begin{tabular}{|c|c|c|c|c|}
\hline No & FS & FT & SPT & Result \\
\hline 1 & Carbu & 88 & STD & \\
\hline 2 & EFI & 88 & STD & \\
\hline 3 & Carbu & 92 & STD & \\
\hline 4 & EFI & 92 & STD & \\
\hline 5 & Carbu & 88 & IRD & \\
\hline 6 & EFI & 88 & IRD & \\
\hline 7 & Carbu & 92 & IRD & \\
\hline 8 & EFI & 92 & IRD & \\
\hline
\end{tabular}

b. Experiment Process

After determining the value of the variable, as in factorial design, it is determining the preparation for conducting the experiment. Some preparations must be made in the trial process.

Preparation of vehicles to be tested:

- Heating the motor to normal temperature and test equipment (Gas Analyzer)

- Check whether there is a leak in the drive motor exhaust system and the test system.

- Idling rotation of the drive motor must be stable and ignition time in accordance with factory specifications.

- After heating is complete, the motor rotation is increased to intermediate rotation \pm 15 seconds without load, then return to Idling rotation (+/$1200 \mathrm{rpm})$.

Testing Process:

- After the motor and test equipment are heated, the next step is to install a gas sensor (gas probe) on the motor exhaust. Make sure the gas sensor installation is $30 \mathrm{~cm}$ deep into the exhaust gas pipe to avoid mistakes. Wait for \pm 20 seconds until the data on the screen is stable.

- Record each result of the test.

- After the first test, do the next test by replacing the type of fuel by emptying the fuel tank first, then refueling the new one and ignition (spark plug).

- After the type of fuel and ignition is replaced, then test the exhaust emissions and record each test result.

\section{Testing Results and Analysis}

The percentage of $\mathrm{CO}$ exhausts gas test results: 


\begin{tabular}{|c|c|c|c|c|c|c|c|}
\hline \multirow{2}{*}{ No } & \multirow{2}{*}{ FS } & \multirow{2}{*}{ FT } & \multirow{2}{*}{ SPT } & \multicolumn{3}{|c|}{ Experiment } & \multirow{2}{*}{$\begin{array}{c}\text { Result } \\
\text { (\%) }\end{array}$} \\
\cline { 5 - 7 } & & & & $\mathbf{1}$ & $\mathbf{2}$ & $\mathbf{3}$ & 1.750 \\
\hline 1 & Carbu & 88 & STD & 1.84 & 1.72 & 1.69 & 0.117 \\
\hline 2 & EFI & 88 & STD & 0.10 & 0.12 & 0.13 & 1.090 \\
\hline 3 & Carbu & 92 & STD & 1.19 & 1.04 & 1.04 & 1.153 \\
\hline 4 & EFI & 92 & STD & 0.16 & 0.15 & 0.15 & 1.617 \\
\hline 5 & Carbu & 88 & IRD & 1.79 & 1.51 & 1.55 & 0.127 \\
\hline 6 & EFI & 88 & IRD & 0.12 & 0.10 & 0.16 & 1.160 \\
\hline 7 & Carbu & 92 & IRD & 1.11 & 1.23 & 1.14 & 0.133 \\
\hline 8 & EFI & 92 & IRD & 0.13 & 0.14 & 0.13 & \\
\hline
\end{tabular}

Analysis using Yates' Algorithm which is to determine the variables that most influence CO. From the results of the analysis obtained:

\begin{tabular}{|c|c|c|c|c|c|c|}
\hline CO $(\%)$ & 1 & 2 & 3 & divider & Result & Effect \\
\hline 1.750 & 1.867 & 3.110 & 6.147 & 8 & 0.768 & Avg \\
\hline 0.117 & 1.243 & 3.037 & -5.087 & 4 & -1.272 & FS \\
\hline 1.090 & 1.743 & -2.570 & -1.073 & 4 & -0.268 & FT \\
\hline 0.153 & 1.293 & -2.517 & 1.160 & 4 & 0.290 & FS,FT \\
\hline 1.617 & -1.633 & -0.623 & -0.073 & 4 & -0.018 & SPT \\
\hline 0.127 & -0.937 & -0.450 & 0.053 & 4 & 0.013 & FS, SPT \\
\hline 1.160 & -1.490 & 0.697 & 0.173 & 4 & 0.043 & FT,SPT \\
\hline 0.133 & -1.027 & 0.463 & -0.233 & 4 & -0.058 & FS,FT,SPT
\end{tabular}

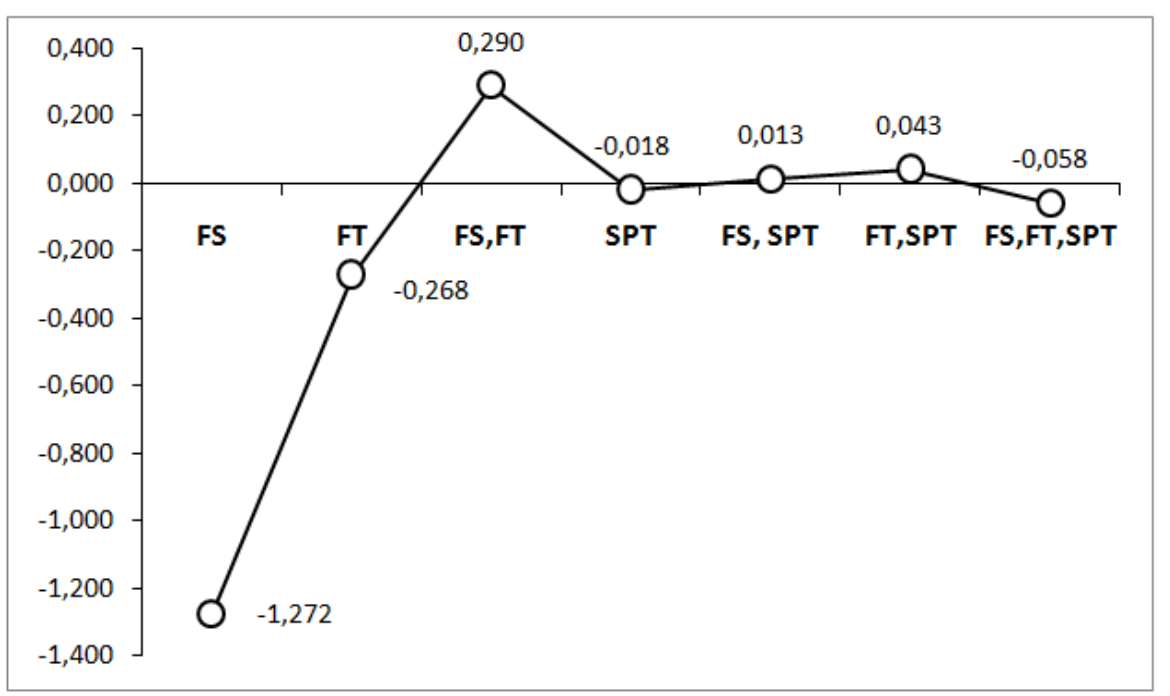

Graph 1. Analysis results 
1. Fuel System Variable (FS) $=-1,272$

This shows that the effect of the fuel system on exhaust gases is $-1,272$. The negative value (-) shows that 2 are variable values ('-' = carburetor system and '+' = EFI system), so the effect on the fuel system is CARBURATOR.

2. Fuel Type Variable (FT) $=-0,268$

This shows that the effect of the type of fuel on the exhaust gas is -0.268 . This is the largest value of all variables tested. A positive value $(+)$ indicates that 2 fuel type variable values ('-" = OCTAN premium 88 and '+ 'pertamax OKTAN 92). So what affects the type of fuel is the PREMIUM OCTANE 88.

3. Spark Plug Type $(\mathrm{SB})=-0,018$

This shows that the effect of spark plug type on the exhaust gas in this condition is -0.018 . A positive value $(+)$ indicates that 2 values of ignition variables ("-" = STANDARD Spark and ' + ' = IRIDIUM Spark). So the variable that most influences the Type of Spark Plug is the STANDARD SPARK PLUG.

\section{Conclusions}

The test results show that the first effect is the fuel system of $-1,272$ (Carburetor), the second effect is the type of fuel of $-0,268$ (Premium), and the third effect is the type of spark plug of $-0,018$ (standard spark plug) $[4,5,6]$. So the variable that most influences the exhaust gas $\mathrm{CO}$ is the fuel system that uses the Carburetor.

It is hoped that there will be further research on other exhaust gases.

\section{REFERENCES}

[1] Gopalan, M. A., Vidhyalakshmi, S., \& Thiruniraiselvi, N. (2014). On Homogeneous Cubic Equation with Fourun knowns $x^{3}+y^{3}=21 z^{2}$. Review of Information Engineering and Applications, 1(2), 93-101.

[2] Collins, Chris (2007) Implementing Phytoremediation of Petroleum. Hal 100

[3] Karthick, K., Premkumar, M., Manikandan, R., \& Cristin, R. (2018). Survey of Image Processing Based Applications in AMR. Review of Computer Engineering Research, 5(1), 12-19.

[4] Jabarullah, N.H. \& Othman, R. (2018) Steam reforming of shale gas over $\mathrm{Al}_{2} \mathrm{O}_{3}$ supported $\mathrm{Ni}-\mathrm{Cu}$ nano-catalysts, Petroleum Science and Technology, DOI: 10.1080/10916466.2018.1547759.

[5] Jabarullah, N.H. (2019) Production of olefins from syngas over $\mathrm{Al}_{2} \mathrm{O}_{3}$ supported $\mathrm{Ni}$ and $\mathrm{Cu}$ nano-catalysts, Petroleum Science and Technology, DOI: 10.1080/10916466.2018.1547758.
[6] Hussain, H.I., Salem, M.A., Rashid, A.Z.A., \& Kamarudin, F. (2019) Environmental Impact of Sectoral Energy Consumption on Economic Growth in Malaysia: Evidence from ARDL Bound Testing Approach, Ekoloji, 28 (107), $199-210$ 